DOI: http://dx.doi.org/10.4314/ljh.v26i1.1

\title{
Traditional Akan Royal Chiefly Institution: Evolving Ceremonial Protocol in Chieftaincy at Duayaw-Nkwanta in Ghana
}

\author{
Godwin Kwafo Adjei \\ Research Fellow, Institute of African Studies \\ University of Ghana, Legon
}

\begin{abstract}
Chieftaincy is one of the most enduring traditional institutions in Ghana that has displayed remarkable resilience from the pre-colonial period to the contemporary era. This article discusses the introduction of new protocolary forms into the institution. Central to the qualitative method deployed is an examination of the interface between "tradition" and modernity" using the 40th anniversary celebration of the paramount chief of DuayawNkwanta, Nana Boakye-Tromo III. In this article, I argue that "traditional elements" are not necessarily at variance with "modern" elements because societies that are often characterized as "modern" also recognize traditions as relevant, rather than as obstacles, to their development.
\end{abstract}

Keywords: Ghana, tradition, modernity, Duayaw-Nkwanta, ceremonial protocol

Tradition, according to Gyekye (1997), should be defined rather as that which is inherited, accepted, and preserved from previous generations than as that which is merely handed down or transmitted from generations (p. 271). He elaborates on this definition with the explanation that cultural values, beliefs, and institutions received from, or bequeathed by, the past can be discarded or disavowed by a subsequent generation ( $\mathrm{p}$. 271). Thus, a present generation, to the extent that it nurtures what it has inherited from the past and places it at the disposal of succeeding generations is more regarded as a maker of tradition than is the original generation that created the values and practices that eventually evolved into a tradition. In summary, tradition is anything that has passed through generations.

\section{Modernity}

Modernity, in the view of Gyekye (1997), can be defined as ideas, principles, and ideals covering a whole range of human activities that have underpinned western life and thought since the seventeenth century (p. 264). One problem that easily stands out is how 
to effectively deal with the controversies between tradition and modernity as forces of modernity can hardly be disregarded in our lives today. Their impact and allencompassing nature in the Ghanaian society have been succinctly described by Assimeng (1996) who observes that even the most illiterate and most rural Ghanaian has been influenced by the type of social changes and the corresponding tempo of modernity that have been going on in the society (p. 9). By modernity, I am referring to things relating to the present or recent times, for example, current smart phones with WhatsApp applications, Internet, digital television, tablets, Viber, Skype, Twitter, and many others.

According to Boas, an anthropologist, all people acculturate and not only the socalled "savages" and minorities. He supports his argument with the statement: "It is not too much to say that there are no people whose customs have developed uninfluenced by foreign culture that has not borrowed arts and ideas which it has developed in its own way (1940, pp. 631- 632). Boas' argument is a vivid manifestation of how individuals or groups have since the period of creation interacted with each other in one way or the other to surge to its present state. From Boas' position therefore, it can be inferred that the borrowing or the introduction of some features from one culture into another culture is a natural phenomenon and not something bizarre. The present paper assesses the relevance of this general ideas to the forms of etiquette observed during the $40^{\text {th }}$ anniversary of a chief in Ghana.

\section{Concept of Anniversary Celebration}

The concept of anniversary celebration in traditional societies is linked with the celebration of traditional festivals and is therefore in harmony with the Akan calendar year, which is divided into nine cycles of forty days called Adae. Two Adaes are observed in every one of the nine cycles, namely the Sunday Adae known as Akwasidae and the Wednesday Adae called Awukudae. The period between one Sunday Adae and the next is forty days, while the Awukudaes are also separated by the same period. The traditional concept of a festival, as noted by Nketia, is that of a communal celebration of life in which the members of a society participate on different levels in a number of structured and unstructured but significant ways (1976, p.33).

Emerging alongside traditional festivals in contemporary Ghana are the anniversary celebrations of the enthronement of chiefs which are often embedded in the celebrations of the annual festival of the traditional area. Though terminologies, such as silver jubilee or golden jubilee are used to describe these celebrations, it is instructive to note that the calculation of the date for such celebrations is based on the Akan nine cycles of forty days which constitute one year (Opoku, 1970). To succeed as a traditional ruler depends on so many factors which include one's ability to serve and account for one's stewardship to one's people from time to time. Furthermore, the chief should be able to thank and honor the gods and ask for their support and assistance in the years ahead. It is 
also important to follow on the achievements of his predecessors to forestall any destoolment charges. In so doing, it is hoped that the gods and the ancestors as well as the subjects will continue to offer chiefs the needed support and cooperation both spiritually and physically to enable them to stay longer on the throne as is the wish of every chief. As Opoku remarks aptly, "the Akan live with the spirits of their dead. They believe that the souls of their dead relatives are still near to them and they call upon them in times of trouble. They ask for their guidance and make them offers of drinks and eggs, and chicken and sheep" (1970, p. 7).

Most traditional African societies have a set of observable rules, which help to strengthen and maintain the sanctity of their institutions in diverse ways. In Ghana, one important institution associated with protocol and its observation and preservation is the institution of chieftaincy which according to Odotei and Awedoba (2006, p.15) remains an important institution of traditional governance in contemporary Ghana. Chieftaincy, from their perspective, is a complex institution with norms and traditions, including achieved and ascribed statuses and roles as well as sets of duties, privileges, rights, and expectations that the stakeholders demand of each other or the public (p. 15). It is to be recognized as an institution that links and interfaces with other institutions in the society and should therefore not be seen as an isolated institution. Addo-Fening (2000) shares in the assertion by Awedoba and Odotei when he asserts that chieftaincy is an institution that shares political and social space with other institutions in the wider society which include both endogenous and exogenous agencies. This is true for many Ghanaian societies, as well as other societies in Africa and other parts of the world.

Chieftaincy has, since the pre-colonial era, undergone many internal changes in its evolution as a traditional political institution, but the most enduring impact on the institution in Ghana, which still continues to shape it, is its encounter with various western actors; first, the traders and merchants, the colonialists and missionaries, and then postindependent African governments. A vivid example is how post-colonial governments, especially the CPP government led by Dr. Kwame Nkrumah undermined the authority of traditional chiefs who were opposed to his modern government administration. On January 5, 1950, Nkrumah tried to coerce chiefs to support his nationalist movement by predicting that unless the chiefs supported the Nkrumah and the CPP, the chiefs might as well lose their sandals once Nkrumah and his party gained control of the post-colonial state (Rathbone, 2000, pp. 22-23; Arhin, 1991, p. 31). All these influences involve challenges that could be described as "modern" to distinguish them from challenges to chieftaincy from its own internal evolution (Addo-Fening, 2000). Even in the midst of external influences, an important distinguishing feature of the chieftaincy institution is that it permeates the very fabric of the Ghanaian traditional society. 


\section{The Chieftaincy Institution in Ghana}

The Akans of Ghana in West Africa have long lived in centralized states under chiefs and kings. Chieftancy has for a long time equally featured prominently in the political life of Ghanaian socities (such as Akwapim, Ga, Guan, and Tampulensi) which originally did not have chiefs and kings. By the early nineteenth century, most of these polities had achieved a high degree of centralization akin to that of their Akan neighbours (Adu 2004, Addo-Fening 2012). The paper now discusses elements that seem to challenge the established protocol of the chieftaincy institution, such as the performance of indigenous customary rites; use of language; greeting of the chief publicly by women within all age brackets; addressing traditional events using a foreign language; and use of contemporary music and musical instruments. The paper begins by examining both old and new protocol within the chieftaincy institution with special reference to the $40^{\text {th }}$ anniversary celebration of the enstoolment of the illustrious chief of Duayaw-Nkwanta.

\section{Study Area and Methodology}

I conducted this research at Duayaw-Nkwanta, one of the principal towns in the Brong-Ahafo Region of Ghana. It is predominantly an Akan-speaking town The BrongAhafo Region is one of the ten regions in Ghana and is located between Northern and Asante Region. It is bordered to the north by the Black Volta River, to the east by the Volta Lake and to the south by the Ashanti Region, and to the west by the Ivory Coast. Its capital is Sunyani. This site is relevant to this research given the view held by Gyekye and Wiredu (1992) that the culture and traditions of towns that are distant from the capital, Accra, are not easily influenced by modern and contemporary trends. The estimated distance of Duayaw-Nkwanta from the capital city, Accra, is one hundred and seventyone kilometers $(171 \mathrm{~km})$, which is about five to six hours drive time.

Methods and perspectives I employed for the research were basically qualitative with emphasis on oral history resources, interviews, focused group discussions, participant observation and audio-visual recording of the anniversary celebration, performances and ceremonies and detailed analysis of performance practices by the court musicians and other traditional and contemporary bands. I conducted interviews before, during, and after the celebration with different categories of persons at different times and locations. I later arranged a focus group discussion with the chief and his elders. This was followed by a focused group meeting with a cross-section of the subjects outside the palace for ratification of additional information on the issues. The number of people interviewed during the field work numbered two hundred and consisted of the following categories of people: traditional elders of the chief's court (20); traders (market women and men(20); elderly men and women within the age bracket of 50 and 70 years either 
with no western education (25) or with western education (30); and the youth within the age bracket of 18 and 35 years with western education up to the senior secondary school level (60), and the educated elite, civil servants and public servants (45). The interviews were later transcribed, interpreted, and analyzed for this paper.

\section{Brief History of Duayaw-Nkwanta}

The origin of the people of Duayaw-Nkwanta from the website of the DuayawNkwanta Traditional Council appears to be shrouded in mystery. According to the legendary history of the area, Nana Dua Yaw I, his queen mother, Nana Serwaa Kesse, and other citizens of the area descended from the sky one fateful day during a heavy thunderstorm. They descended by a golden chain (atweaban) and landed at the Nkwanta (crossroad) where the town is now located in a very big shining brass basin in the sacred forest called "Mankwe mu" popularly known as "Kannianko," about three miles from the location of the present town. According to oral history, Nana Dua Yaw I and his people decided to settle at the crossroad around $1600 \mathrm{AD}$, and named the place Nkwanta. Later, they moved to Asuogya just behind the Apaape River (abankesiemonline.org /index.../history/33-the-origin-of-duayaw-nkwanta)

\section{Brief Profile of Nana Boakye-Tromo III}

Nana Boakye-Tromo III was born at Nkwanta in 1926 and christened Samuel Edward Osei after his baptism in 1967. He was the son of Madam Akua Bomo and Opanin Debrah, both of Duayaw-Nkwanta. He had his elementary education at the Nkwanta Presbyterian Primary School and Bechem Presbyterian Middle School. After his elementary education, he entered Odumasi-Krobo Presbyterian Secondary School from 1947 to 1951 where he obtained his Cambridge School Certificate. He then proceeded to the Presbyterian Training College at Akropong-Akuapem in 1952 where he qualified as "a Certificated 'A' teacher" in 1953. In effect, he had all his formal education in Ghana, but while his elementary schooling was undertaken in his native Brong-Ahafo Region (Duayaw-Nkwanta and Bechem), his second cycle education took place in the Eastern Region (Odumasi-Krobo and Akropong-Akwapim). On 31 ${ }^{\text {st }}$ July 1967, Samuel Edward Osei was enstooled as the Dmanhene (paramount chief) of Duayaw-Nkwanta Traditional Area with the stool name Nana Tromo III.

\section{Ceremonial Protocol}

\section{Coexistence of Tradition and Modernity}

Protocol, according to Merriam Webster learner's dictionary, is "a system of rules that explain the correct conduct and procedures to be followed in formal situations," by states and institutions. One finds a high level of indigenous sophistication, manners, cultures, and beliefs, which were ignored and are still misconceived by outsiders and the 
educated elite alike. Each traditional system has its goal orientations as well as behavioral and social norms around which the system revolves. The behavioral norms are closely associated with the systems of authority and roles as they are legitimized in various clusters, such as the family, the chieftaincy hierarchy, the state council, and other structures from which authority is derived and exercised. The goal orientation refers to the types of expectations that were built into the traditional system. They guide individuals to view their future and direct their activities towards achieving them. The social norms refer to the rules regarding rewards, sanctions, festivals, rituals, and sacrifices. Guides to political and other social behavior are enunciated in proverbs as proverbial laws. These proverbs often stem from the past and are associated with good and bad lessons learnt from experiences and observation; they are orally transmitted from generation to generation.

In Ghana, as in most of Africa, the root of protocol or etiquette can be traced to the chieftaincy institution purported to have come into existence around 1300, long before the arrival of the Europeans on the shores of the country. It is recognized as the custodian of the culture and traditions of a people, hence its responsibility to enact a set of rules to preserve certain values of the society. These formalities, which Agyekum (2003) refers to as semiotic honorifics, are manifested generally at the palace of traditional chiefs. Honorifics, thus, refer to specialized address and deference forms used to show politeness and competence in language and culture. They also point to various aspects of social identity and are status-indexing speech forms reflecting social asymmetries (Agha 1994; Anderson 1993; Ide 1989).

As an institution, chieftaincy seems buoyant in contemporary Ghana, but it owes much of its continued survival and social relevance to its skillful response and adaptation to the forces of social change. The institution as noted is encased in a series of traditional rules and regulations that are intended to protect the culture and traditions of its people from western forms of acculturation. In consequence of this, protocol and other related procedures are required to be observed to the letter by the institution during major traditional events such as the anniversary celebration of chiefs. This paper is an ethnographic perspective and analysis of some of the observable evolving protocol that took place on the last day of the $40^{\text {th }}$ anniversary celebration of Nana Boakye-Tromo III.

As protocol demands, any major traditional event is often climaxed with a procession along some selected principal streets of the town with the carrying of the paramount chiefs and other wing chiefs in palanquins. On the occasion of the $40^{\text {th }}$ anniversary celebration of Nana Boakye-Tromo III, all the important chiefs and subchiefs flanked by their elders and queen mothers and sections of their subjects and accompanied by drummers paraded the principal streets of the town before arriving at the durbar ground. On reaching the durbar ground, the chiefs and their entourage paraded round the field of the durbar amidst drumming and dancing to extend their greetings to 
the teeming crowd before they finally settled down to await the arrival of the paramount chief, Nana Tromo III.

Moments later, the paramount chief Nana Tromo III was spotted coming towards the durbar ground in a Mercedes Benz car for health reasons, led by some of the young court functionaries and accompanied by the fontomfrom drummers in a pickup vehicle. As soon as the paramount chief Nana Tromo III arrived at the durbar ground, all the subchiefs and the general crowd rose up for him while the vehicle drove him round to extend his greetings to the crowd, amidst cheers and praises. After the exchange of greetings with the people, the chief was driven to take his seat under a well-decorated modern canopy, where a special dais had been erected for him. The traditional convention is that during such traditional events, it is only the fontomfrom drumming that is used to welcome the paramount chief and his entourage to the durbar ground. While the fontomfrom is performing, all other bands, particularly contemporary bands present are expected to remain silent.

In this instance however, the youth band that was in attendance, out of over excitement, also started playing alongside the traditional drumming which in fact was against traaditional protocol. Nonetheless, it is worth noting that no traditional chief worth his sort keeps contemporary musical instruments in his court or dances to contemporary music publicly. To this end, during the $40^{\text {th }}$ anniversary celebration of Nana BoakyeTromo III, a vast range of traditional bands was assembled and invited to play at different times. Among these traditional bands were different groups of kete bands, adowa groups, a fontomfrom band from the chief's court, and another from the Sunyani Cultural Center played by only females. A cultural troupe from one of the senior high schools was also present to perform on the atumpan (talking drums) principally to eulogise the chief on his achievements and also to grace the occasion. It was these traditional bands that actually added special touch and color to the occasion as the elders of the court, children as well as women who are skilled in traditional dances moved in to the dancing arena at different times to display their dancing skills during performances by the traditional bands.

In addition to the traditional bands, a youth band and a brass band were in attendance to support the occasion, even though they did not fall into the category of court music bands. Instruments assembled by the youth band were mainly of western origin and included a table-top organ, a jazz set, and a conga (a pair of tall traditional drums). Though the repertoire of the youth band consisted mainly of gospel songs in English and a few secular rap songs in the Asante-Twi dialect of Akan, the entire audience made up of both the youth and the elders danced joyfully to their music anytime it was their turn to perform. Because of this, the bandsmen sometimes got overexcited and often jumped in unexpectedly to play even when it was not their turn to perform.

As tradition demands, the chief is normally accompanied at traditional functions by the fontomfrom band. Unfortunately, this traditional norm could not be maintained 
during the $40^{\text {th }}$ anniversary celebration of Nana Boakye-Tromo III, because of frequent interruptions by the youth band. This can best be seen as an evolving trend since a youth band is not recognized as producers of court music, and should therefore not be used to interrupt a traditional event. These interruptions often created what one may be tempted to refer to as "cacophony" and miniature chaos as the two strands of music did not agree in terms of timbre. Apart from the discord, it also tended to mar the beauty of the event, as one could not establish whether it was a traditional function, a contemporary concert, or a church service. As a result of this, some concerned observers began to shout and remark, "Na $\varepsilon$ dec ben koraa na cre kosoo yi?" (i.e., "But what at all is going on?"). It was quite an embarrassing situation and so intermittently were the interruptions that the youth band had to be beckoned to exercise some level of restraint to enable the aesthetics of the traditional bands to feature more prominently in the ceremony. An announcement by one of the elders got them to tone down a little and enabled people to actually behold traditional performance in its real perspective as chiefs and their followers now got the opportunity to display their skills in fontomfrom dancing.

\section{The Dkyeame (Spokesperson) and MC}

Since the inception of the chieftaincy institution in Ghana, a key person responsible for the organization of traditional events has often been the skyeame (spokesperson) because of his proficiency in the language of the people and also, on account of his close association with the chief and events of the court throughout the year. Among the Akan of Ghana for example, persons of royal status, particularly traditional rulers, are expected to maintain dignified silence during periods of catastrophe. Whatever the chief has to say is expected to pass through the skyeame (spokesperson) whom Yankah (1995) describes as the focus of all formal interaction in the royal domain, whether social or verbal. If chiefs speak at all, their speech is marked by sophisticated understatements and measured deliberation (Sutherland-Addy, 2006, p. 247; Fosu, 2005, p. 54).

Contrary to traditional protocol, this important role of the skyeame has been subverted, for as was observed at the $40^{\text {th }}$ anniversary celebration, the role has now been assigned to what is referred to as a "Master of Ceremonies" (MC) because of modernity and rapid social change. The position, "master of ceremonies," is a term that has evolved as a result of modernization, globalization, and rapid social change. Undoubtedly, these MCs for the most part speak a foreign language, particularly English, which most of the indigenes that are non-literate do not understand very well. Meanwhile, this is an evolving trend that has come to be accepted by contemporary society, as people often pride themselves on the ability of their chief (and MCs) to speak English, even when they do not understand much of it. 


\section{Sitting Posture}

Sitting with crossed legs, particularly in front of the chief and his elders publicly is frowned upon by tradition. It is in fact considered unethical and anyone seen in this posture is immediately described as arrogant, uncouth, and disrespectful. Unfortunately, this appeared as one of the most glaring scenes during the $40^{\text {th }}$ anniversary celebration of Nana Boakye-Tromo III. While the chief was going round to greet the invited guests and other chiefs and dignitaries in attendance, a lot of people were already seated some with crossed legs. Though this was glaring, no one had the courage to prompt anybody about it due to frequent observation of similar actions on television and the Internet.

\section{Greeting of the Chief by Women}

Years ago, it was a real taboo for a woman to greet a chief or go near him while in her menses. Writing generally and exclusively about women in Ghana, Assimeng notes that various myths, taboos, customs, and traditions had historically assigned women to a socio-politically inferior status (1990, p. 58). Consequently, in the days when communal wars were rampant, most families, individuals, and states, particularly chiefly institutions needed to fortify themselves spiritually against their enemies. At most of the shrines that they consulted for their fortification, chiefs and warriors were cautioned against contact with women in their menstrual period (Jkyeame Kwasi Ampofo (Interview 2008). The menstrual blood according to the interviewees had the potential of neutralizing their spiritual powers.

The platform on which menstrual blood is often articulated is that of concepts of purity and pollution that Ortner (1978) sees at the heart of the belief system of most cultures. According to her, cross-culturally, purity and pollution are observed and experienced virtually as the contagion of pollution, which left to its own devices, spreads and overpowers all that it comes in contact with. In spite of these precautions, all categories of women both young and old during the Duayaw-Nkwanta function in question went round, one after the other, to greet the paramount chief publicly during the ceremony. While the traditionalists may be thinking of a possible case of some women being in their menses, majority of the people may frown upon this belief because of their Christian faith. Any attempt to enforce it will thus lead to their decline of invitation to attend such traditional functions in the future.

\section{Chief's Use of Foreign Language at Traditional Events}

Traditionally, a chief is required to address his subjects during important traditional events in the indigenous language, which the people understand better than English. Unfortunately, the language, which Nana Boakye-Tromo III used to address the gathering during the ceremony, was English. Though it was a well-prepared speech, the applause of many of the indigenes in attendance was cosmetic as they often had to wait 
for the MC to signal them to clap before they could do so. Meanwhile, in traditional societies the chief is very much appreciated and lauded by his people when he is able to speak eloquently in the indigenous language, particularly when he is able to intersperse his speech with proverbs, metaphors, and other figures of speech. But this linguistic departure from established norms is also to be seen as an evolving trend because for many people, English is an international language that everyone needs to learn and speak as it is more like the first language of the country now.

Chiefs have since the adoption of the chieftaincy institution reserved the power and the right to sanction any subject who behaved contrary to any of the procedures of the state. Before the period of colonialism in Ghana around the 16th century, sanctions of a heavy fine or death penalty depending on the gravity of the offence were imposed on culprits, particularly among the Asante. For example, there is the story of a young man of Dompoase, a town in the Asante Region who was deemed to have deliberately exhibited disrespectful behavior through his use of symbolic gestures during his dance performance at the Dompoasehene's palace, (the palace of Dompoase chief) thereby generating conflict between himself and the chief and his elders present. By his conduct, he was deemed to have treated the office and person of the chief with contempt. For his punishment, he was made to slaughter a sheep in accordance with customary practice (Bame, 1991, p. 159). In contemporary Ghana where western democracy now permeates the entire society however, no chief reserves the right to sanction a subject for exhibiting dance gestures he considers offensive. As a result, during the $40^{\text {th }}$ anniversary celebration of Nana Boakye-Tromo III, people, particularly the youth were seen displaying their own dancing skills and gestures with ease. Even to the beat of the fontomfrom drumming, the youth were seen using Azonto ${ }^{l}$ techniques and style to dance to it openly. Though it looked strange to use contemporary dancing styles to dance to the beat of the traditional fontomfrom music, it is worth noting that the dancing styles and gestures exhibited by the youth were so exciting and stimulating that almost everybody in attendance was compelled to voluntarily applaud at intervals in appreciation. As a result of the excitement, people were unable to focus and read any meaning into the dancing gestures on display to decipher it as something disrespectful to the chief.

1 Azonto is an African dance form which originated in Ghana during the early 2000s. It is a dance form which incorporates and coordinates complex body movement and non-verbal communication in a rhythmic fashion in very few one-two timed steps. Just like most African dances, knee bending and hip movements are required to dance it. 


\section{Other Traditional Forms of Etiquette}

Within the different traditional areas in Ghana, there are a variety of rules that are observed, particularly in the courts of chiefs and also during festive and ceremonial occasions. Among such important customs are invitations of elders to meetings by the traditional ruler, which are carried out by drums with coded messages (Addo-Dankwa, 2004, p. 43). In many parts of Ghana, these coded messages are played on the drums three times at intervals of approximately thirty minutes. The first beating of the drums serves as a general notice to all who are required by custom to attend the meeting to get prepared.

The second beating is a signal for every chief and his elders to be either present at the palace or to make their way to the palace. With the exception of the paramount chief, all elders and sub-chiefs are required to be seated during the third beating of the drums. At the end of the third beating of the drums, the paramount chief enters the meeting hall, and as custom demands, everybody is required to stand up to acknowledge him and also wait for him to take his seat before they also resume their seat (Addo-Dankwa, 2004, p. 43). It is important to point out that, even though the position of the town crier (gong beater) has not been abolished from the court of the chief, because of rapid urbanization and modern technology, most traditional rulers now use mobile phones to communicate with their elders on very important and urgent issues. Drums are still used alongside, but sparingly, as the use of the contemporary medium of communication is deemed to work faster and helps to save time and energy.

When a paramount chief has taken his seat at an assembly of chiefs and elders, the skyeame (spokesperson) announces this and invites the elders to come forward to exchange greetings with him. The hand shaking is done hierarchically, starting from the most junior to the most senior elder or chief. The most senior chief, as tradition demands, always returns the greetings generally through the spokesperson. In greeting the chief, one is expected to take off his/ her sandals before shaking hands with him and then return to put them on when they return to their seats (Denteh, 1967, p. 10). On this occasion, however, a lot of people went to greet the chief and his elders wearing their footwear. These included both the locals and foreigners in attendance.

By protocol when a chief is moving round to exchange greetings, everybody in attendance is expected to keep standing and wait for him to finish and return to his seat before a signal is given for the general crowd to also take their seats. Once again, on this occasion, by the time the chief had finished with his rounds to take his seat, a lot of people were already seated. Though this was against protocol, no sanction could be preferred against anybody as a result of modernity and rapid social change.

On the same basis, if one has his/her hat on, he/she will have to remove it before proceeding to greet the chief (Nana Dmankrado Ansah, Interview, 2011). A probable question one is likely to ask is "Why are women not required to remove their scarves when it is their turn to greet the chief?" The argument here is that, traditionally, the 
wearing of headscarves has always been a fundamental part of a traditional Akan woman's dressing long before the arrival of the Europeans in Ghana in 1471. It is significant to note that dukuu (Akan word for headscarves), doek in Dutch and $d u g$ in Danish, according to Christaller (1933), was introduced by the Dutch during their arrival in Ghana in the year 1637. Until then, the women dressed by wearing what is referred to as shew, a kind of girdle with long fringes, made of the fibers of the adobe (raffia palm) and worn by traditional priests when performing rites. The women at this period in question did not wear any scarf or $d u k u u$ on their hair. All they did was to use black thread to weave the hair into various styles and designs of their choice. Though Christaller's claim may be true, as a result of contemporary ignorance of what existed in Akan communities long before being conquered by their colonial enemies, the perception of most people is that the wearing of the odoso (raffia skirt) is for only traditional priests who are ready to perform for their gods. Worse of all, with the influence of Christianity and western education, any woman who attempts to dress in the outfit of this odoso to functions may immediately be tagged an idol worshipper. It is important here to stress that the wearing of headscarves over kaba and a cover cloth has traditionally been the fundamental dressing of women and though a traditional practice, it is just modernity of the past few hundred years.

The wearing of the traditional attire $k a b a$ and cover cloth without scarves fundamentally cannot adequately showcase the true beauty of an African woman, and is therefore considered a very important part of a woman's dressing. Forcing a woman to remove her scarves in the name of protocol therefore could be interpreted as an act of sabotage to make her look "naked" in terms of her beauty. It is therefore to avoid such abhorrence that women are allowed to greet or shake hands with the chief with their scarves on.

\section{Discussions of Results}

In this study, I sought the perception of people on the acceptance of evolving protocol by chiefs and its impact, either positive or negative, on the chieftaincy institution. Some of the questions asked during the interviews include the following:

(a) Questions (Qs) to a retired public servant: What is your view about the use of an MC for a traditional ceremony like the celebration of the 40th anniversary of your paramount chief instead of the state Dkyeame (spokesperson)?

Response: We think because the ceremony involved the attendance of both local and international dignitaries most of whom are literate and may know only the English language it was appropriate to employ the services of an $\mathrm{MC}$. The skyeame (spokesperson) as most of us are aware can only speak the indigenous language through no fault of his. Furthermore, looking at the changing trends in this 
contemporary era; some of us do not see anything wrong with the use of the services of a Master of Ceremonies who is professionally trained for such events.

(b) Qs to retired public servant: But don't you think in so doing you'll be weakening the position of the skyeame as the spokesperson of the chief?

Response: Well, that's the reason why the planning committee found it necessary to meet him over it in advance before the services of the MC were engaged.

(c) Qs. Ok, but can one say majority of the subjects in attendance understood the language of the $\mathrm{MC}$ which for the most part was in English?

Response: Well, not everybody; but some will certainly ask for assistance from the educated folks around.

(d) Qs to an elder at the chief's court. Good afternoon, Nana Fredua: Dwumadie a modii cnne da yi fa amammere a esombo paara, nanso mehunu se nnecmmafor nnosma pii frafra mu, adcn ntira? ("I see today's program to be strictly a traditional affair, but looking round, I see that it is mixed up with so many things of this contemporary period, why?")

Response: Well, the youth band was invited to draw more people, particularly the youth to the function, which to some of us see is a positive move. The youth now dominate the population of the town and for every program to get on well, it is imperative that we do all we can to involve them in it. Moreover, they have the strength and the energy to take on board some of the activities that we cannot do now. Additionally, we the aged love brass band music to such an extent that we always feel dignified anytime it is played. In fact, it serves as a magnetic force that has the capacity to pull us out in our numbers to events that employ it.

(e) Qs. Okyeame, enne dwumadie a ckossos yi, na me nim se wo na wobedi biribiara anim nanso manhunu no saa, aden ntira?

"Linguist I thought you were going to preside over the entire ceremony that took place today, but that was not what I saw; why?"

Response: Ansaana dwumadie no rebedurusos no, nana tuu mpaninfor a na dwumadie no hye wonnsa behuu me se wobepese wode dwumadie no nyinaa behye okasafos (MC) a wagye din wo Sunyani mpstamu ha no nsa. Mfitiasec no m'ani annye ho, nanso esiane nkyerckyercmu a wodekaa ho no nti nactwa se megye to mu na biribiara atumi aks so scnea smanfo dodos no hwehwe no. ("Well, before the commencement of the celebration, members of the planning committee consulted me, on behalf of the chief, over who to preside over the ceremony for things to get 
on smoothly as expected by the public. I was thus persuaded to accept their explanation").

Asembisa: Enti wonnye nni se cbema wo tumi se okyeame no so ahwan aba fam?

("By so doing, don't you think your status as a spokesperson is going to be devalued?")

Dkyeame: Daabi, daabi, daabi. Jman no ye yen nyinaadea enti nea smanfo hwehwe no na ese se yeye de ma won.

("Not at all; the state belongs to all of us and so we need to respond to the needs of the people accordingly.")

(f) Qs. Teacher Kwarteng. What can you say about Nana Boakye-Tromo III with respect to infrastructural development since his installation as chief of DuayawNkwanta?

Response: Teacher Kwarteng (Retired): As far as some of us are concerned, we see Nana Boakye-Tromo III as one of the most progressive chiefs Duayaw-Nkwanta has ever had. Some of us have lived in this town for over twenty-five years and the kind of unity, peace, and oneness coupled with other developmental projects we have enjoyed under his regime is unparalleled. He is someone who devoted the greater part of his time, resources, and energy to the general infrastructural development of the town. Some of his achievements in practical terms include the construction of feeder roads to link surrounding villages, and the establishment of many basic schools and second cycle institutions. Recently, he has released a vast stretch of land for the construction of a Sunyani Polytechnic campus and has also established Tromo Educational Fund to help brilliant, but needy students from the traditional area. Another achievement worth mentioning is the reconstruction of the town roads. As you could see yourself, all the town roads are all well fixed without any disgusting portholes. Until his installation as chief of Duayaw-Nkwanta, all these roads were almost impassable. To a great number of us therefore, Nana BoakyeTromo III is in fact a brilliant intellectual and a visionary person worth his salt as a paramount chief.

\section{Analysis of Findings}

The findings show that although there was a time when chieftaincy was perceived as anachronistic, particularly in the era after independence, the chieftaincy institution, in its entirety, continues to enjoy the goodwill of many Ghanaians. The findings show that about $90 \%$ of respondents support the acceptance of evolving protocol into the chieftaincy institution, particularly in this modern era. The practice of using MC for important functions has come to be accepted as part of contemporary culture and is seen as a means 
of creating gainful employment for the youth. In a similar vein, the practice of using youth bands with modern musical instruments at traditional ceremonial events, for most of the interviewees, is not to be seen as something bizarre, particularly in a country where the active population is dominated by the youth. According to the 2010 population census of the country, almost one out of every four people in Ghana was reported to be aged 20-35 years. However, persons between 15-35 years, who form the youth according to the National Youth Policy, constitute about a third of the population of Ghana. If this startling statistics on the youth population is anything to go by, then the probability of rejecting evolving protocol into the chieftaincy institution cannot be guaranteed. Any attempt to force its rejection is likely to have dire consequence on the future growth and development of the institution as participation by the youth in the programs of the institution may begin to wane. Generally, most of the interviewees greatly appreciate the traditions and culture of the institution, but hold the view that they could be practiced contemporaneously with evolving trends.

An important claim by the queen mother during my interview, for example, is that it is against traditional norm for queen mothers to be accompanied with fontomfrom drumming during processions which in fact makes such celebrations very boring to them. Most of them now see themselves as Christians and are able to use their resources to hire brass bands that play Christian songs in the form of choruses to accompany them during such events. Brass band music, the queen mother argues, is enjoyed by both the youth and the aged and should be used therefore to support traditional functions. The use of English to address subjects and other dignitaries in attendance at traditional functions is now hailed by society as the desire of every town or village in the country is to get a literate person as their chief, a chief, who is not just educated, but is also able to speak English eloquently. Further, the greeting of the chief by both sexes publicly is not seen as anything offensive in contemporary Duayaw-Nkwanta. Human rights advocates are ever ready to defend anyone who may be sanctioned by any traditional authority on account of perceived departure from traditional norms. The data shows that majority of the respondents in the different age categories are all in full support of the integration of evolving protocol into the chieftaincy institution.

\section{Conclusion}

In conclusion, I wish to reiterate the fact that since society is dynamic and will continue to be dynamic, there is no way tradition can detach itself completely from the influences of modernity. For example, apart from the chieftaincy institution there is even a wider space in which we can observe these changes, such as in the areas of popular culture (churches). In consequence of global influences and internal initiatives, the youth who now constitute a significant part of society have developed new tastes for so many things, including music and dance. There is therefore the need for traditional societies to 
create additional space and platforms for them to practice their creative talents and skills so as to recognize themselves as part of society.

Tradition is never static. It evolves with the times, and so will continue to interact in various ways with each other as was observed at Duayaw-Nkwanta where traditional and modern bands were both employed during an important traditional function. And it is important to note that what happened at Duayaw-Nkwanta is not an exceptional case or unique to the town. The youth have become so indispensable to the success of almost every traditional event that virtually every chief of modern Ghana ensures their total involvement in the planning and execution of their traditional programs. In consequence of this, it should no more sound bizarre to find brass bands and youth choirs performing alongside traditional bands at typical traditional functions. But in each case, a mechanism will need to be put in place to streamline their performances to prevent confusion or unnecessary chaos.

Finally, I wish to recapitulate the fact that tradition and modernity are not necessarily contradictory or exclusive. They are merely two different phenomena moving in a continuum where each can borrow from the other whenever necessary. 


\section{References}

Addo-Dankwa, N. (2004). The institution of chieftaincy 2004: The future.Accra, Ghana: Konrad Adenauer Foundation.

Addo-Fening, R. (2000). Akyem Abuakwa 1700-1943: From Ofori Panyin to Nana Sir Ofori Atta. No 19 Trondheim Studies in History. African Series, 1.

Addo-Fenin, R. (2012). Chieftaincy, colonialism and the atrophy of traditional Governance in Ghana. In H. Lauer \& K. Anyidoho (Eds.), Reclaiming the human successes and humanities through African perspectives (pp. 683702). Accra, Ghana: Sub-Saharan Publishers.

Adu-Boahen, A. (2004). Ghana evolution of tradition and change in the nineteenth and twentieth century. Accra, Ghana: Sankofa Educational Publishers.

Agha, A. (1994). Honorification. Annual Review of Anthropology, 23, 277-302.

Agyekum, K. (2003). Honorifics and status indexing in Akan communication. Journal of Multilingual and Multicultural Development, 24 (5), 369-385.

Anderson, E. A. (1993). Speech levels: The case of Sudanese. Pragmatics, 3, (2).107-136.

Arhin, K. (1991). The economic and social aspects of the re-accommodation of Ghanaian returnees from Nigeria in 1983 and 1985, paper delivered at the UNRISD Symposium on social and economic aspects of mass voluntary return of refugees from on Africa country to another. Harare, Zimbabwe, pp 12-14.

Assimeng, M. (1990). Women in Ghana: Their integration in socio-economic development. Research Review, 6 (1), 57-68. .

Assimeng, J. M. (1996). An anatomy of modern Ghana. Accra, Ghana: Ghana Academy of Arts and Sciences.

Bame, K. N. (1991). Profiles in African traditional popular culture: Consensus and conflict; dance, drama, festivals and funerals. New York, NY: Clear Type Press.

Boas, F. (1940). The aims of ethnology. Reprinted in F. Boas, Race, language, and culture (pp. 626-638). New York, NY: Macmillan. (Original work published 1888.)

Christaller, J. G. (1933). Dictionary of the Asante and Fante language called Tshi (Twi) ( $2^{\text {nd }}$ ed.). Basel, Switzerland: Basel Evangelical Missionary Society.

Denteh, A. C. (1967). A Visitor's guide to Ghanaian customs and other matters. Legon, Ghana: Institute of African Studies.

Fosu, K. (2005). Amammere 20. Kumasi, Ghana: Cita Press.

Gyekye, K. (1997). Tradition and modernity. Oxford, UK: Oxford University Press.

Ide, S. (1989). Formal forms and discernment: Two neglected aspects of 
universals of linguistic politeness. Multilingual Journal of Cross-Cultural and Interlanguage Communication, 8,223-248. http://dx.doi.org/10. 1515/ mult.1989.8.2-3.223

Nana Pmankralo Ansah. (2011). Interview (August 6).

Nketia, J. H. K. (1982). Interaction through music: The dynamics of music making in African societies. International Social Science Journal, 34(4), 639-656.

Odotei, I. K., \& Awedoba, A. K. (Eds.), (2006). Chieftaincy in Ghana: Culture, governance and development, 1. Accra, Ghana: Sub-Saharan Publishers.

Opoku, A. A. (1970). Festivals of Ghana. Accra, Ghana: Ghana Publishing Corporation.

Ortner, S. B. (1978). Is female to male as nature is to culture? In M. Z. Rosaldo \& L. Lamphere (Eds.), Woman, culture, and society (pp. 68-87). Stanford, CA: Stanford University Press.

Dkyeame Ampofo. (2008). Interview (September 3).

Rathbone, R. (2000). Nkrumah \& the chiefs: The politics of chieftaincy in Ghana 1950-60. Athens, OH: Ohio University Press.

Sutherland-Addy, E. (2006). Projecting royalty: The evocative power of the poet at court. In I. Odotei \& A. K. Awedoba (Eds.), Chieftaincy in Ghana (pp. 247 -261). Accra, Ghana: Sub-Saharan Publishers.

Wiredu, K. \& Gyekye, K. (1992). Person and community: Ghanaian philosophical studies. Washington, D.C.: Council for Research in Values and Philosophy.

Yankah, K. (1995). Speaking for the chief: Okyeame and the politics of Akan royal oratory. Bloomington, IN: Indiana University Press.

Submitted: August 11, 2015 / Published: May 30, 2016 